\title{
Molecular regulation of visual system development: more than meets the eye
}

\author{
Takayuki Harada, ${ }^{1,2}$ Chikako Harada, ${ }^{1,2}$ and Luis F. Parada ${ }^{1,3}$ \\ ${ }^{1}$ Department of Developmental Biology and Kent Waldrep Foundation Center for Basic Neuroscience Research on Nerve \\ Growth and Regeneration, University of Texas Southwestern Medical Center, Dallas, Texas 75235, USA; ${ }^{2}$ Department of \\ Molecular Neurobiology, Tokyo Metropolitan Institute for Neuroscience, Fuchu, Tokyo 183-8526, Japan
}

\begin{abstract}
Vertebrate eye development has been an excellent model system to investigate basic concepts of developmental biology ranging from mechanisms of tissue induction to the complex patterning and bidimensional orientation of the highly specialized retina. Recent advances have shed light on the interplay between numerous transcriptional networks and growth factors that are involved in the specific stages of retinogenesis, optic nerve formation, and topographic mapping. In this review, we summarize this recent progress on the molecular mechanisms underlying the development of the eye, visual system, and embryonic tumors that arise in the optic system.
\end{abstract}

For humans, the visual system is a principal conduit for acquiring external sensory information. Thus, "quality of vision" is intimately tied with "quality of life." Despite extensive clinical and laboratory investigation, many diseases that impair vision, ranging from congenital abnormalities to sporadic forms of retinal degeneration, lack effective treatments. One hope is that improved understanding of development of the visual system, from the eye to the visual cortex, will provide insight into methods for attenuating or reversing these disorders. Development of the neural retina and visual system, especially the mechanism of axon remodeling during synaptogenesis, is complex. Studies have shown that numerous genes are involved in the differentiation and formation of the retina acting at specific stages of the development of visual system. In this review, we will summarize recent progress on the molecular mechanisms underlying the development of the eye and visual system.

\section{Anatomy of eye development}

The basic components of the complex optic system are derived from four embryonic sources: forebrain neuroec-

[Keywords: Retinal development; degeneration and regeneration; retinal ganglion cells; axon guidance; topographic mapping; neurotrophins; cancer]

${ }^{3}$ Corresponding author.

E-MAIL luis.parada@utsouthwestern.edu; FAX (214) 648-1960.

Article is online at http://www.genesdev.org/cgi/doi/10.1101/gad.1504307. toderm, intercalating mesoderm, surface ectoderm, and neural crest (Fig. 1). The neuroectoderm differentiates into the retina, iris, and optic nerve; the surface ectoderm gives rise to lens and corneal epithelium; the mesoderm differentiates into the extraocular muscles and the fibrous and vascular coats of the eye; and neural crest cells become the corneal stroma sclera and corneal endothelium. The vertebrate eye originates from bilateral telencephalic optic grooves. In humans, optic vesicles emerge at the end of the fourth week of development and soon thereafter contact the surface ectoderm to induce lens formation. When the lens placode invaginates to form the lens vesicle, the distal part of optic vesicle begins to invaginate to form the optic cup. As the optic vesicles grow, the proximal ends expand and their connections with the forebrain constrict to form optic stalks. Through the retinal fissure, a groove at the inferior aspect of the optic vesicle, the hyaloid artery, enters the eye and nourishes the optic cup and lens vesicle. The retinal fissure normally closes at $\sim 7 \mathrm{wk}$ of development, and proximal parts of the hyaloid vessels persist to form the central artery and vein of the retina, a branch of the ophthalmic artery. Defects in closure of the fissure result in coloboma, defined as defects of the iris, retina, choroid, and optic nerve, depending on their extent. The retina develops from the walls of the optic cup with the outer, thinner pigmented layer forming the retinal pigment epithelium (RPE) and the inner, thicker neural layer differentiating into the neural retina. The neural layer contains photoreceptors (rods and cones) and other neural cell types, such as bipolar and ganglion cells (Fig. 2). The axons of retinal ganglion cells (RGCs) residing in the surface layer of the neural retina grow proximally into the wall of the optic stalk to the brain, and gradually form the optic nerve. The pathfinding and orientation of the retinal ganglion innervation at the superior colliculus (SC) or dorsal lateral geniculate nucleus (dLGN) reflects the stereotypic orientation of the neuronal somata within the retina.

\section{The neural retina}

The vertebrate retina is composed of six types of neurons and one type of glia (Müller glia), which constitute three 


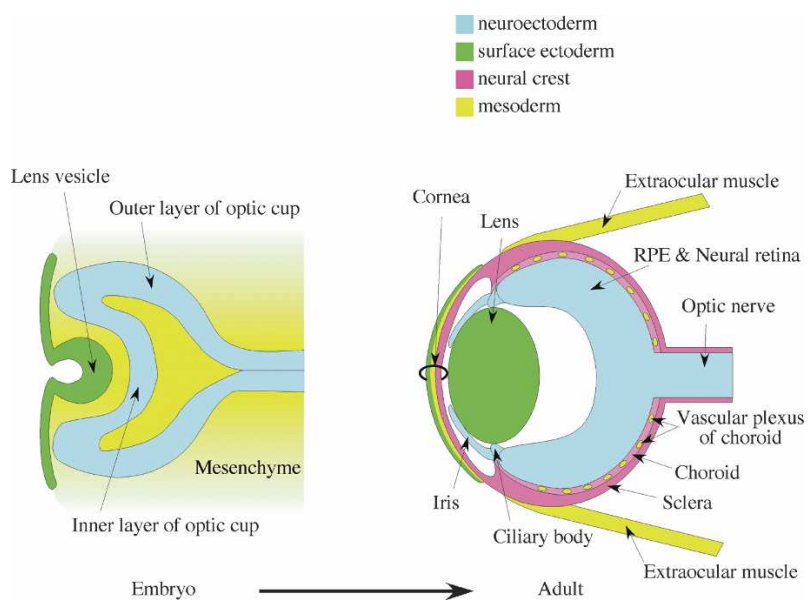

Figure 1. Embryonic lineages that contribute to the eye. (Blue) Forebrain neuroectoderm; (green) surface ectoderm; (yellow) mesoderm; (pink) neural crest. Note that the layers of the optic cup fuse to form the RPE and the neural retina, and extend anterior to form the ciliary body and iris.

nuclear layers: RGCs in the ganglion cell layer (GCL); horizontal, amacrine, bipolar, and Müller glial cells in the inner nuclear layer (INL); and rod and cone photoreceptors in the outer nuclear layer (ONL) (Fig. 2). The cell types are produced in an orderly manner that is generally conserved in vertebrates (Cepko 1999; Marquardt and Gruss 2002; Hatakeyama and Kageyama 2004). During retinogenesis, these seven cell types derive from a common population of retinal progenitor cells residing in the inner layer of the optic cup. There are four important steps in the process of generating the mature retina from retinal progenitor cells. Retinal progenitor cells must expand through cell division, exit the cell cycle, commit to a particular cell fate, and then execute the differentiation program for the committed cell type. Lineage analyses have revealed that retinal progenitor cells are multipotent and retain their ability to generate different cell types up to the final cell division (Turner and Cepko 1987; Holt et al. 1988; Wetts and Fraser 1988; Turner et al. 1990). As summarized in Table 1, numerous recent misexpression and loss of function studies have identified that retinal development is controlled primarily by transcription factors of the basic helix-loop-helix (bHLH) and homeobox families (Marquardt and Gruss 2002; Hatakeyama and Kageyama 2004). It is thought that homeodomain factors regulate layer specificity while bHLH activators determine cell fate within the homeodomain factor-specified layers (Figs. 2, 3). For example, both Math5 and Pax6 are expressed by RGC progenitors and required for RGC formation (Brown et al. 2001; Marquardt et al. 2001; Wang et al. 2001). Adjacent, early progenitor cells that coexpress Math3 and NeuroD (Inoue et al. 2002) together with Pax6/Six3/Prox1 (Dyer et al. 2003) or Pax6/Six3/Lim1 (Liu et al. 2000) adopt the amacrine or horizontal cell fate in the INL. Coexpression of NeuroD/Mash1 and Otx2/Crx may induce photoreceptor development in the ONL (Furukawa et al. 1997).
Later, progenitor cells that express Mash1/Math3 with Chx10 differentiate into bipolar cells (Tomita et al. 2000; Hatakeyama et al. 2001). Still other, misexpression studies using retrovirus have shown that bHLH repressors Hes1/Hes 5 promote generation of Müller glial cells from later progenitor cells at the expense of neural differentiation (Furukawa et al. 2000; Hojo et al. 2000). Thus, bHLH factors have critical regulatory functions from progenitor cells to each of the emergent differentiated cell types.

Another important modulator of retinal progenitor cell competence is the growth and differentiation factor 11 (GDF11), a member of transforming growth factor- $\beta$ (TGF $\beta$ ) superfamily. GDF11 does not affect progenitor proliferation, but controls the duration of expression of various bHLH and homeobox genes including Math5, Pax6, and Prox1 (Fig. 3, arrows). In so doing, GDF11 ultimately controls the temporal window of competence and thus the relative numbers of retinal cell types (Kim et al. 2005). For example, GDF11 down-regulates Math5 expression causing progenitor cells to lose competence to form RGCs. Instead, they now acquire competence to produce later-born cell types. Consistent with this, GDF11-null mice show an increased number of RGCs at the expense of amacrine cells and photoreceptors (Kim et al. 2005). Proliferation of retinal progenitors may also be partly controlled by extrinsic cues such as ciliary neurotrophic factor (CNTF), bone morphogenetic protein (BMP), and fibroblast growth factor (FGF) molecules; however, these effects appear independent of fate and differentiation cues among both early and late progenitor cells (Cepko 1999; Yang 2004).

Table 1. Expression of homeobox and bHLH genes in the retinal progenitor cells

\begin{tabular}{|c|c|c|c|}
\hline Gene & Group & Cell type & Reference \\
\hline pax6 & homeobox & $\begin{array}{l}\text { ganglion } \\
\text { amacrine } \\
\text { horizontal }\end{array}$ & Marquardt et al. 2001 \\
\hline six3 & homeobox & $\begin{array}{l}\text { amacrine } \\
\text { horizontal }\end{array}$ & Oliver et al. 1995 \\
\hline $\operatorname{ch} \times 10$ & homeobox & bipolar & Liu et al. 1994 \\
\hline prox1 & homeobox & amacrine & Dyer et al. 2003 \\
\hline $\lim 1$ & homeobox & horizontal & Liu et al. 2000 \\
\hline $\operatorname{crx}$ & homeobox & cone/rod & $\begin{array}{l}\text { Chen et al. 1997; } \\
\quad \text { Furukawa et al. } 1997\end{array}$ \\
\hline otx2 & homeobox & cone/rod & Nishida et al. 2003 \\
\hline $\operatorname{rax}$ & homeobox & Müller & Furukawa et al. 2000 \\
\hline math5 & bHLH & ganglion & $\begin{array}{l}\text { Brown et al. 2001; } \\
\text { Wang et al. } 2001\end{array}$ \\
\hline neuroD & bHLH & $\begin{array}{l}\text { amacrine } \\
\text { cone/rod }\end{array}$ & Morrow et al. 1999 \\
\hline math3 & bHLH & $\begin{array}{l}\text { amacrine } \\
\text { bipolar } \\
\text { horizontal }\end{array}$ & Tomita et al. 2000 \\
\hline mash1 & bHLH & $\begin{array}{l}\text { bipolar } \\
\text { cone/rod }\end{array}$ & Tomita et al. 1996b \\
\hline hes1 & bHLH & Müller & Tomita et al. 1996a \\
\hline hes5 & bHLH & Müller & Hojo et al. 2000 \\
\hline hesr2 & bHLH & Müller & Satow et al. 2001 \\
\hline
\end{tabular}



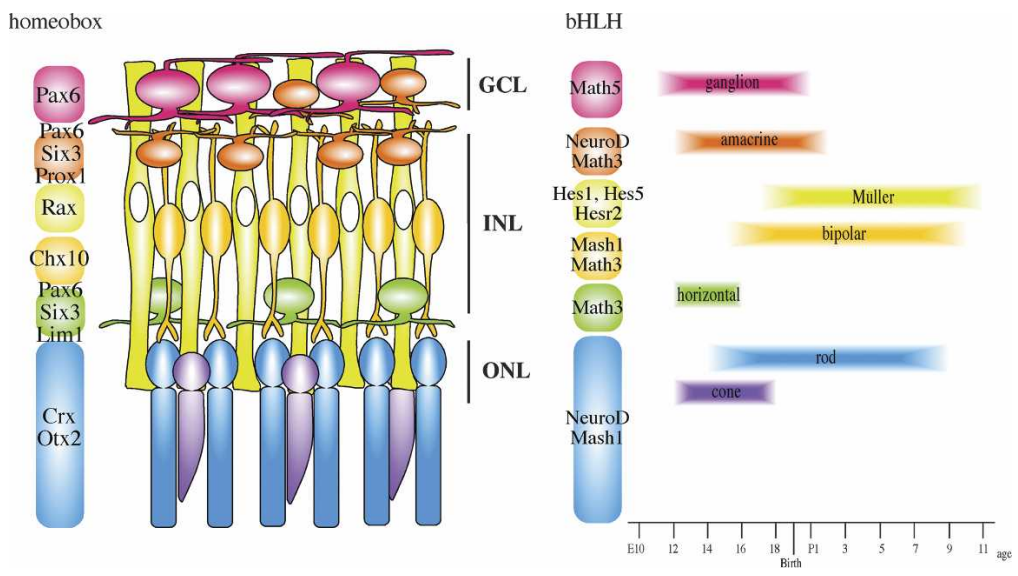

Figure 2. Retinal cell fates. Three major divisions-GCL, INL, and ONL-give rise to seven retinal cell types that arise from common multipotent progenitors in a fixed order. The RGC is the first neuronal cell type and Müller glia appear last. Homeodomain and bHLH transcription factors cooperate as intrinsic regulators to define the layer specificity and the neuronal cell fate. Hes1 inhibits neuronal differentiation and maintains progenitor cells. The cells that sustain Hes1/Hes5 expression during neurogenesis stages adopt the final available cell fate of Müller glial cells. (Bottom right) The relative timing of cell appearance is for mouse development.

During development, nearly half of RGCs experience programmed cell death (PCD) (Perry et al. 1983). Many transcription factors, neurotrophic factors, cell deathregulating factors, and caspases have all been implicated in the regulation of developmental RGC death (Isenmann et al. 2003). Neurotrophins induce neural cell survival and differentiation during retinal development through the high-affinity tyrosine kinase (Trk) receptors (von Bartheld 1998). Additional reports have suggested that NGF binding to the low-affinity neurotrophin receptor $\mathrm{p} 75\left(\mathrm{p} 75^{\mathrm{NTR}}\right)$ might induce PCD in the early phase of retinal development (Frade and Barde 1999). There are two periods of cell death in the developing murine retina. The first peak occurs during embryonic days 1517 (E15-E17), and is the main onset of neurogenesis, neural migration, and initial axon growth. Recent evidence identifies post-mitotic RGCs at the optic nerve exit undergoing $\mathrm{p} 75^{\mathrm{NTR}}$-induced PCD (Harada et al. 2006). However, retinal morphology, RGC number, and BrdUpositive cell number in $\mathrm{p} 75^{\mathrm{NTR}}$ mutant mice is normal after E15. In chick retina, migrating RGCs from the ventricular to the vitreal surface of the retina express p $75^{\text {NTR }}$, whereas layered RGCs express the high-affinity NGF receptor TrkA, which may switch the proapoptotic signaling of $\mathrm{p} 75^{\mathrm{NTR}}$ into a neurotrophic one (GonzalezHoyuela et al. 2001). In contrast to the chick model, mouse migratory RGCs express TrkA, while stratified RGCs express $\mathrm{p} 75^{\mathrm{NTR}}$ in retina, and RGC number in TrkA mutant mice is normal (Harada et al. 2006). In addition, expression of TGF $\beta$ receptor, which modulates chick RGC number in combination with $\mathrm{p} 75^{\mathrm{NTR}}$, is absent in mouse RGCs. These findings suggest different mechanisms for RGC number control between mouse and chick retina.

The second period of retinal PCD coincides with the phase of tectal and thalamic innervation and synapse formation. In the rat, $\sim 50 \%$ of the total RGC population dies in the first postnatal week soon after reaching their target axons, the SC, and the dLGN (Perry et al. 1983). While BDNF or NT-4/5 injected into the SC promotes the survival of neonatal RGCs (Cui and Harvey 1995; Ma et al. 1998), BDNF or NT-4/5 mutant mice have normal RGC numbers and double-mutant mice show delay in the inner retinal development (Cellerino et al. 1997; Harada et al. 2005). Thus, neurotrophins and their receptors seem to be differentially involved in RGC apoptosis according to the developmental stage. Additional studies to determine the functions of both mature neurotrophins and proneurotrophins (Nykjaer et al. 2004; Teng et al. 2005; Woo et al. 2005) may uncover the detailed mechanisms of RGC number control and axon remodeling.

\section{Adult retinal stem cells}

Retinal stem cells can be isolated from the pigmented ciliary margin of the adult mouse and human eyes (Tropepe et al. 2000). Although the number is small in the adult ciliary margin, Wnt3a can increase the self-renewal of retinal stem cells via the canonical pathway (Inoue et al. 2006). In addition, a glycogen synthase kinase3 (GSK3) inhibitor mimics the proliferative effect of Wnt3a, which is partly dependent on FGF signaling. These results may provide a novel therapeutic strategy for in vitro pooling or in vivo activation of retinal stem cells derived from the adult ciliary margin. Thus, the understanding of developmental retinogenesis and its stenotopic molecular codes described above may one day lead to production of specific neuronal subtypes from retinal stem cells as well as embryonic stem cells (Ikeda et al. 2005).

Müller glial cells may also have progenitor-like regenerative potential after mild injury and trophic factor stimulation (Ooto et al. 2004; Fischer 2005). Müller cells are thought to carry out many of the functions provided by radial glia, astrocytes, and oligodendrocytes in the CNS (Harada et al. 2000). Thus, the retinogenic potential may be closely related to neurogenic function of the radial glial cells in the cerebral cortex (Campbell and Gotz 2002; Alvarez-Buylla and Lim 2004).

\section{Retinal polarity}

In addition to the ordered appearance of retinal cell types, another important genetic influence on retinal progenitor cells is their positional identity as reflected in 
Figure 3. Extrinsic control of transcription factors for retinal cell type specification. GDF11 controls the number of RGCs by suppressing Math5 expression and causing progenitors to acquire competence to produce later-born cell types such as amacrine cells and photoreceptors. GDF11 promotes expression of various homeodomain genes (black) such as Pax6 and bHLH factors (green) including NeuroD.

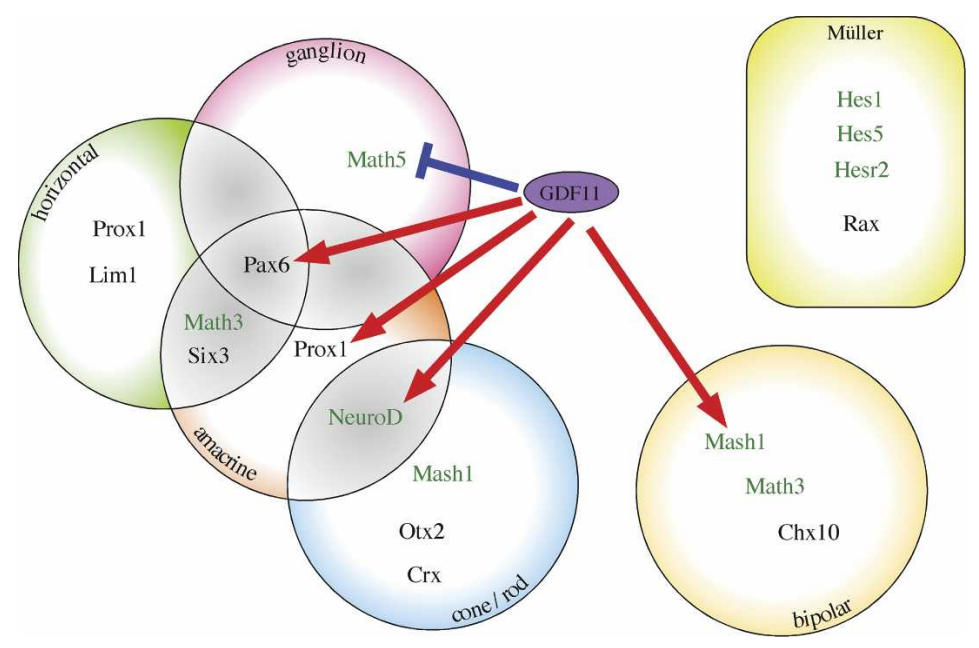

the subsequent organization of polarity and topographic maps. Although the direct comparison between humans and other species is difficult, several transcription factors have recently been identified that establish nasaltemporal $(\mathrm{N}-\mathrm{T})$ and the dorsal-ventral $(\mathrm{D}-\mathrm{V})$ retinal polarity (Peters 2002; McLaughlin et al. 2003a). Pax6 has a principal role, since it is required for the normal regulation of both $\mathrm{N}-\mathrm{T}$ and $\mathrm{D}-\mathrm{V}$ axis regulatory genes, thus exerting its importance beyond the early development of the eye cup (Baumer et al. 2002). As summarized in Figure 4, the $\mathrm{N}-\mathrm{T}$ axis is set earlier than the D-V axis. First, polarized expression of the two winged-helix transcription factors, brain factor-1 (BF1) and BF2, divides the optic stalk and the retina into nasal and temporal domains (Hatini et al. 1994). Misexpression of BF1 or BF2 results in misprojection on the chick tectum, showing that these transcriptional factors control the positional identity in RGCs along the N-T axis (Yuasa et al. 1996). Next, two homeobox containing genes, SOHol and GH6, are expressed in a nasal-high and temporal-low pattern (Schulte and Cepko 2000). Thereafter, EphA5 and EphA6 are expressed in a high-to-low T-N gradient (Brown et al. 2000).

Once N-T polarity is determined, D-V polarity develops initially through the opposing actions of dorsally restricted BMP4 and ventrally derived sonic hedgehog (Shh) signals regulating the growth and specification of the optic primordium (Zhang and Yang 2001). Ventroptin, a ventrally localized BMP4 antagonist, also negatively regulates the dorsalizing effect of BMP4 (KoshibaTakeuchi et al. 2000; Sakuta et al. 2001). Next, Tbx5, an apparent target of BMP signaling, is expressed in dorsal retina. Thus, in chick retina, ectopic BMP4 expression expands the Tbx5 field into ventral retina, followed by enhancement of dorsal markers ephrin-B1 and ephrin-B2 and repression of ventral markers cVax (see below), EphB2 and EphB3 (Koshiba-Takeuchi et al. 2000). In contrast, ectopic expression of Shh results in dorsal inhibition of BMP4 and enhanced expression of ventral cVax (Zhang and Yang 2001). The Vax2 transcription factor (mouse homolog of cVax), is expressed ventrally with overlapping timing to that of BMP4. Ectopic Vax2 expression down-regulates dorsalizing factors including BMP4, Tbx5, ephrin-B1, and ephrin-B2, while up-regulating the ventralizing mediators EphB2 and EphB3 (Schulte et al. 1999). Vax2-null mice have severe defects in D-V organization, and the dorsal-high and ventral-low expression patterns of ephrin-B1 and ephrin-B2 become flattened (Mui et al. 2002).

To add further complexity, studies have reported that several genes regulating retinal polarity have graded expression patterns that are not limited to a single axial pattern, suggesting an interplay of regulation for both axes (Koshiba-Takeuchi et al. 2000; Sakuta et al. 2001; Mui et al. 2002). For example, Vax2 has a shallow N-T gradient in addition to its strong $\mathrm{D}-\mathrm{V}$ gradient (Mui et al. 2002). BF1 mutant mice exhibit both N-T and D-V patterning defects associated with ectopic expression of BF2 and specific loss of Shh, respectively (Huh et al. 1999). Thus, current understanding places Pax6 at the beginning of a hierarchy that is followed by $\mathrm{N}-\mathrm{T}$ axis specification followed by D-V alignment. Disruption of preceding regulatory steps apparently has consequences on all subsequent events.

\section{The optic nerve and ganglion cell axon pathfinding}

The RGC is the only retinal neuron that projects and conveys visual information to the brain. Once retinal polarity is established, RGCs extend axons to the optic nerve head at the central retina, form the optic nerve and chiasm, and establish retinotopic maps in the SC. Here again, Shh signaling appears to hold important roles. Shh is expressed in the center of the prechordal plate and up-regulates Vax1 and Pax2 in the optic stalk. The induction of these two genes negatively controls the expression of Pax6 in the optic cup (Macdonald et al. 1995; Hallonet et al. 1999). Later, Shh secreted from RGCs maintains Pax2 in the optic stalk and disc via Vax1 expression, which is necessary for their specification as glial cells (Bertuzzi et al. 1999; Dakubo et al. 2003). 


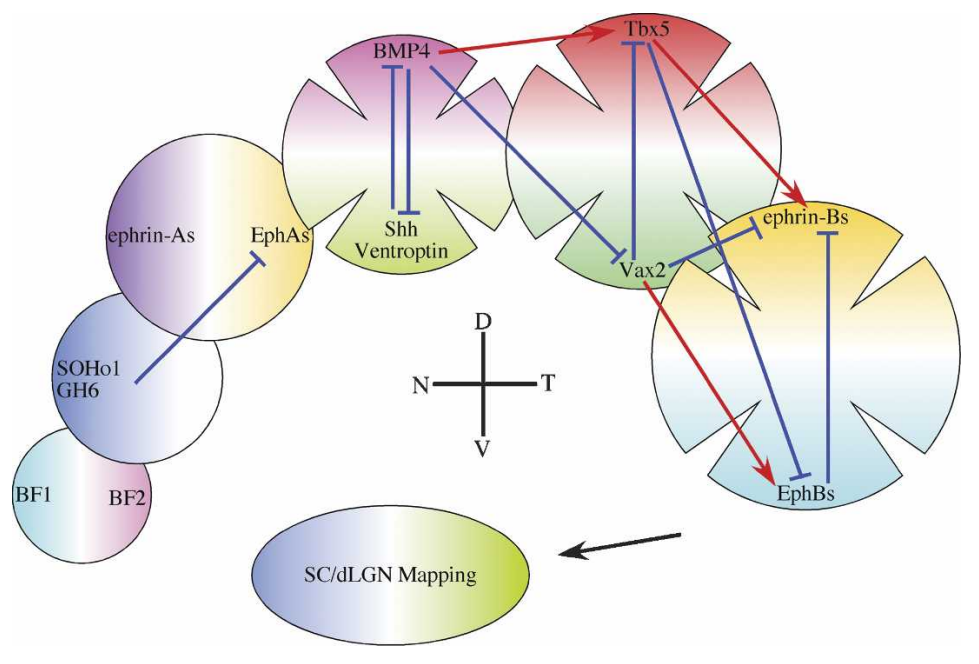

Figure 4. Molecular control of retinal polarity. Early in retinal development, BF1 and BF2 mark the nasal and temporal retina. Subsequently, two nasal markers, SOHol and GH6, are expressed in nasal retina. Both SOHol and GH6 can repress the expression of EphA3 at later stages. D-V polarity develops soon after N-T polarity is established. BMP4 expression in the dorsal retina and Shh and Ventroptin in the ventral retina couteract one another. BMP4 activates Tbx5 and represses Vax2. Tbx5 activates ephrin-Bs and suppresses EphBs. Vax2 enhances the transcription of EphBs and repress ephrin-Bs. Arrows represent transcriptional activation and T-bars indicate transcriptional repression. (SC) Superior colliculus; (dLGN) dorsal lateral geniculate nucleus; (D) dorsal; (V) ventral; (N) nasal; (T) temporal.
The optic nerve undergoes gliogenesis similar to general CNS gliogenesis. Oligodendrocyte type-2 astrocyte precursor cells (O-2As) are born in the floor of the third ventricle and migrate into the optic nerve toward the eye (Ono et al. 1997). During migration, O-2As differentiate into oligodendrocyte precursor cells (OPCs) and type-2 astrocyte precursor cells. Migratory direction of OPCs is regulated by attractive guidance molecule netrin-1, secreted from cells concentrated in the optic disc and in the temporal quadrant of the optic nerve (Spassky et al. 2002). OPCs are inhibited from migrating into the retina beyond the optic nerve head, while type- 2 astrocyte precursor cells distribute in the retina (Watanabe and Raff 1988; Sugimoto et al. 2001). Type-1 astrocytes are derived from optic stalk neuroepithelium and represent the largest glial cell population in the optic nerve. These astrocytes are thought to provide a structural support for RGC axons and a scaffold for OPC migration (Tsai and Miller 2002). The projecting RGC axons provide Shh signal for expansion of the astrocyte precursor cell population in the embyronic optic nerve (Dakubo et al. 2003) and additional growth/trophic factors for the proliferation of type- 1 astrocytes in the first postnatal week (Burne and Raff 1997).

During the long distance of axon pathfinding, RGC growth cones are navigated by a succession of different guidance cues expressed in their local environment (Oster and Sretavan 2003; Rasband et al. 2003; Mann et al. 2004; Williams et al. 2004). The first pathfinding task for RGCs is to exit the eye through the optic nerve. Chondroitin sulphate proteoglycan inhibits RGC axon growth and controls the initial direction of axons (Brittis et al. 1992). As shown in Figure 5, a ring of chondroitin sulphate prevents RGC axons from spreading toward the peripheral retina, thus confining extension toward the central optic disc. In addition, axon guidance molecules, such as L1, netrin-1, and laminin-1, are involved in retinal axon exit at the optic disc leading to optic nerve formation (Mann et al. 2004). L1 is a member of immunoglobulin family of cell adhesion molecules, and blockade of L1 function severely disrupts radial growth cone orientation and rate of outgrowth (Brittis et al. 1995). In netrin-1-deficient retinas, many RGC axons fail to exit into the optic nerve, resulting in optic nerve hypoplasia (Deiner et al. 1997). Similar abnormalities are observed in mice mutant for the netrin-1 receptor, deleted in colorectal cancer (DCC), which is expressed on RGC axons (Deiner et al. 1997). Interestingly, laminin-1 changes netrin-1 attraction to repulsion at the entrance of the optic nerve head, which may help steer retinal axons into the optic nerve (Hopker et al. 1999). In addition to these guidance cues, EphB receptors have redundant functions in RGC axon pathfinding. RGC axons from dorsal retina bypass the optic disc in EphB2; EphB3 double mutants, without affecting the expression of other guidance cues (Birgbauer et al. 2000, 2001). Similar intraretinal guidance errors are not detected in single knockout of EphB1-3 or EphB1; EphB2 double mutants (Williams et al. 2003). Thus, a proper balance of repulsion and attraction helps RGC axons to navigate in the correct direction toward the optic disc.

\section{Optic glioma}

The most common tumor of the optic tract is the optic glioma or pilocytic astrocytoma. This is usually a benign (WHO type I) tumor whose growth can impair visual function. Formation of optic glioma typically occurs in childhood and is connected to abnormal gliogenesis during embryonic and early postnatal periods (Maher et al. 2001; Zhu and Parada 2002). The majority (70\%) of childhood optic gliomas are associated with the genetic disease Neurofibromatosis type 1 (NF1) (Listernick and Gutmann 1999). NF1 acts as a tumor suppressor by inhibiting Ras activity and suppressing Ras-mediated cell growth. Conditional knockout (Cre/lox) strategies have been employed to model NF1-initiated optic gliomas in mice. These studies have provided evidence that induction of NF1-associated optic gliomas requires the heterozygous state of nontumor tissues in addition to loss of NF1 in astrocyte lineage (Bajenaru et al. 2002; Zhu et al. 2005). Thus, as known for other NF1-associated tumors, 


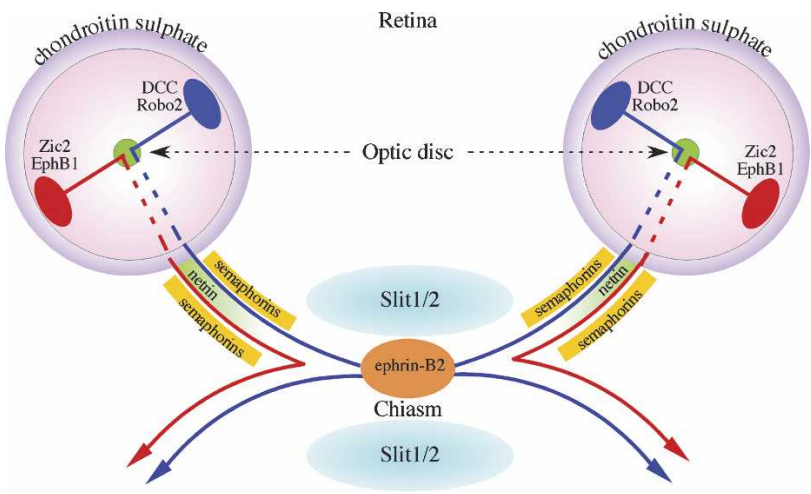

Figure 5. RGC axon guidance. In the retina, axons are repelled from the periphery by chondroitin sulfate. At the optic disc, RGC axons exit the retina into the optic nerve using a mechanism based on attractive netrin/DCC-mediated action. Within the optic nerve, RGC axons are kept within the pathway through semaphorin distribution and by inhibitory Slit/Robo interaction. Slits also contribute to positioning the optic chiasm by creating zones of inhibition. Zic2-expressing RGCs in the VT retina project EphB1-expressing axons, which repel ephrin-B2 at the optic chiasm and terminate ipsilateral targets.

amplified paracrine interplay between sources of mitotic stimulus in the microenvironment and the NF1-nullizygous cells may be at the root of tumor induction. Further studies to reveal the detailed mechanisms in the formation of optic glioma may produce more widespread benefit in the management of NF1.

\section{Retinal axon guidance and formation of the optic chiasm}

The optic chiasm is the structure where partial contralateral crossover of RGC axons occurs. Netrin-1 likely exerts its attractant influence on RGC axons after they exit the eye (Fig. 5). However, netrin-1 is not present around the chiasm midline where RGC axons come under the influence of repulsive molecules such as Sema5A and Slit/Robo (Fig. 5). Sema5A is expressed at the optic disc and along the optic nerve, and blockade of Sema5A function causes retinal axons to stray out of the optic nerve bundle (Oster et al. 2003). It is possible that Slit/ Robo signaling may define the site of optic chiasm formation. RGCs express Robo2, a receptor for Slit. Slit1 and Slit2 are present in the ventral diencephalon. Individual mouse knockouts of Slit1 or Slit2 show few RGC axon guidance defects but double mutants develop a large additional chiasm anterior to the true chiasm, and many RGC axons project into the contralateral optic nerve and some extend dorsal or lateral to the chiasm (Plump et al. 2002). Similar studies remain to be performed on Robo2 knockout mice (Long et al. 2004). The available data support a "surround repulsion" model, in which Sema5A and Slit proteins acts as a repulsive "guardrail" establishing a corridor through which RGC axons are channeled.

Heparan sulfates (HS) are also implicated in RGC pathfinding. In neuron-specific conditional knockout mice of
EXT1, the HS-polymerizing enzyme, RGC axons project ectopically into the contralateral optic nerve (Inatani et al. 2003). These data are reminiscent of Slit1; Slit2 double-mutant phenotypes (Plump et al. 2002). A recent study showed that cell surface HS promotes Slit-Robo binding and is important for the repulsive activities of Slit2 protein (Hu 2001). Moreover, reduction of one allele of EXT1 in Slit2 knockout mutants causes similar axon misguidance at the optic chiasm (Inatani et al. 2003). These results demonstrate a strong dosage-sensitive genetic interaction between Slit2 and EXT1, indicating that HS plays an essential role in Slit-mediated axon guidance at the optic chiasm. In humans, the optic chiasm lies directly above the diaphragma sallae. Anatomic variations, in which the chiasm is situated more anterior $(10 \%)$ or posterior $(10 \%)$ are not uncommon. The guidance molecules discussed above may thus affect the precise anatomical location of the human optic chiasm.

\section{Divergent cues for uncrossed projections at the optic chiasm}

In the former section, we reviewed recent progress on the mechanism of optic chiasm formation and contralateral crossing over of retinal axons. However, in most mammals, RGC axons derived from the temporal retina avoid the midline and project ipsilaterally (Jeffery 2001). The degree of uncrossed axons is $<5 \%$ in the mouse, but nearly $50 \%$ in humans. This arrangement at the level of the optic chiasm is necessary for acquiring high-quality binocular vision and stereopsis. Ephrin-B2 and EphB1 control axon divergence at the optic chiasm (Williams et al. 2003). Ephrin-B2 is expressed in radial glial cells at the optic chiasm concurrent with the development of the ipsilateral projections, and the blockade of ephrin-B2 eliminates the ipsilateral projection in mice. The EphB1 receptor is specifically expressed in RGCs in the mouse ventrotemporal (VT) retina that give rise to the ipsilateral projection (Fig. 5) and EphB1 mutants reveal a strong reduction in the number of ipsilateral projections (Williams et al. 2003). EphB1; EphB2; EphB3 triple mutants exhibit no more severe phenotype compared with the EphB1 single mutant, indicating an absence of redundancy such that only EphB1 may be up-regulated in growth cones as they enter the chiasm region (Williams et al. 2003).

Several regulatory genes expressed in the developing retina indirectly control ipsilateral projections through regulation of ephrin-B2 and/or EphB1. For example, in Vax2-null mice, ephrin-B2 expression is extended to the ventral retina, but EphB2 is almost absent (EphB1 expression was not examined) (Barbieri et al. 2002). In addition to such a molecular dorsalization of the developing retina (see Fig. 4), Vax2 mutant mice were reported to have almost complete absence of ipsilateral projections (Barbieri et al. 2002). This phenotype was not reproduced in an independent study (Mui et al. 2002). Another candidate for regulating ipsilateral projections is the zincfinger transcription factor Zic2 that is expressed in dif- 
ferentiated VT RGCs when the ipsilateral projection is formed (Herrera et al. 2003). In VT RGCs, Zic2 expression is spatiotemporally identical to that of EphB1 and the loss- and gain-of-function analyses indicate that Zic2 is sufficient to switch the outgrowth behavior of retinal axons from crossed to uncrossed patterns in response to inhibitory cues from chiasm cells. In addition, genetic hypomorphs of Zic2 display reduced ipsilateral projection. The phenotype appears similar to that of EphB1 mutants, although these mice also exhibit abnormal RGC axons that project between the optic nerve and chiasm. These findings suggest that Zic2 may control the ipsilateral projection by directly regulating multiple guidance genes including EphB1. The proportion of Zic2expressing cells correlates with the spatiotemporal features of the formation of the uncrossed projection in such diverse species as the mouse, ferret, Xenopus, and chick, and reflects the degree of binocularity in each of these species, implicating Zic2 function in patterning binocular vision throughout evolution (Herrera et al. 2003).

\section{Ephrins and molecular control of topographic mapping}

Upon crossing the midline, RGC axons project to their major targets: the SC and the dLGN. Topographic mapping of RGC axons occurs along two sets of orthogonally oriented axes. The $\mathrm{N}-\mathrm{T}$ axis of the retina maps along the posterior-anterior ( $\mathrm{P}-\mathrm{A})$ axis of the $\mathrm{SC}$, and the $\mathrm{D}-\mathrm{V}$ retinal axis along the lateral-medial (L-M) SC axis. Accumulating evidence has revealed that ephrin-As and their EphA receptors are required for proper retinal N-T mapping along the SC P-A axis (Brown et al. 2000; Wilkinson 2000; McLaughlin and O'Leary 2005). In mouse retina, EphA5 and EphA6 are expressed in a decreasing gradient from temporal to nasal axons, while ephrin-A2 and eph-
rin-A5 from the posterior to the anterior SC (Fig. 6). The EphA-ephrinA repellent interactions between RGCs and the SC, impedes high EphA-expressing RGC axons from terminating in the ligand-rich posterior part of the SC (Fig. 6, blue and black axons) while permitting low EphA-expressing RGCs to invade (Fig. 6, red axons). In ephrin-A2; ephrin-A5 double-mutant mice, both temporal and nasal RGCs exhibit mapping defects, and the ectopic terminations of nasal RGCs are found anterior to their correct P-A sites (Feldheim et al. 2000). These results support the idea that EphA gradients in the retina and ephrin-A gradients in the SC may operate in combination with axon-axon competition in map formation. Graded EphA receptor expression in the SC and ephrinA expression in the retina also influences A-P positioning (Fig. 6). For example, EphA7 shows the strongest anterior-high and posterior-low expression in the SC, but is absent in the retina. A recent study showed that EphA7 is a repellent substrate for retinal axon growth in vitro, and topographic mapping of both temporal and nasal axons is disturbed in EphA7 mutant mice (Rashid et al. 2005). One recent study reported that an external gradient of Engrailed-2, a homeodomain transcription factor, repels growth cones of Xenopus axons originating from the temporal retina, but attracts nasal axons (Brunet et al. 2005). In engrailed-misexpressing chicken tectum, Eph ligand family 1 (ELF-1) and repulsive axon guidance signal (RAGS) that belong to the family of ligands for Eph-related receptor tyrosine kinases are up-regulated (Logan et al. 1996). In addition, axons from nasal retina frequently arborized at various sites including the inappropriate anterior tectum (Itasaki and Nakamura 1996). Taken together, Engrailed-2 may also participate in the formation of $\mathrm{P}-\mathrm{A}$ axis in the vertebrate SC, possibly by regulating the expression of Eph family members (Drescher et al. 1997).

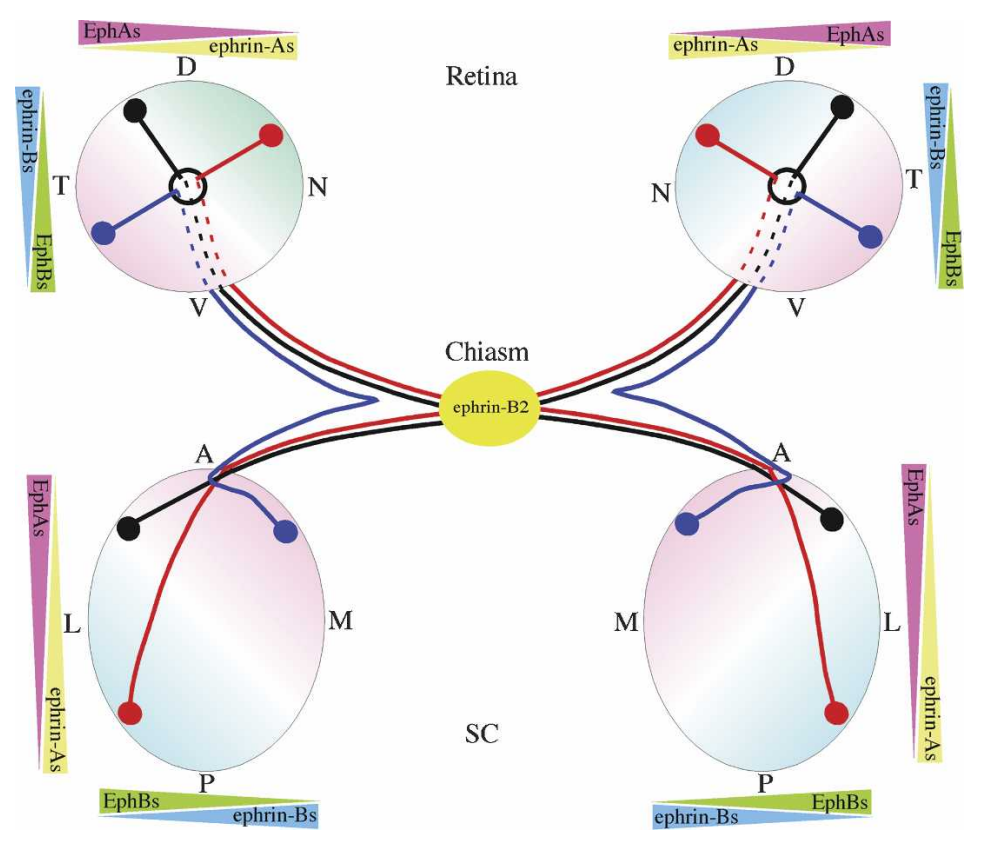

Figure 6. Regulation by Eph/ephrin in retinocollicular topographic mapping. RGC axons are distributed to specific target zones by responding to gradients of ephrin ligands in SC. The high-to-low PA gradient of ephrin-As in SC inhibits the posterior extension of growth cones at various positions, depending on RGC EphA level. Axons from temporal retina, which express high levels of EphA receptors, map to the anterior part in SC (blue and black axons) while low-EphA-expressing RGCs from nasal retina can invade into the more posterior part (red axons). On the other hand, the attractant effect of EphB/ephrin-B interactions is responsible for L-M mapping. Axons from ventral retina, which express high levels of EphB receptors, map to the medial part in SC (blue axons) while low-EphB-expressing RGCs from dorsal retina map to the lateral part (black and red axons). (D) Dorsal; (V) ventral; (N) nasal; (T) temporal; (A) anterior; (P) posterior; (L) lateral; (M) medial. 
Ephrin-Bs in the SC and their EphB receptors in the retina are also required for proper $\mathrm{D}-\mathrm{V}$ mapping along the L-M axis (Hindges et al. 2002; McLaughlin and O'Leary 2005). EphBs are expressed in a low-to-high D-V gradient by RGCs, and ephrin-B1 is expressed in a lowto-high L-M gradient in the SC (Fig. 6). EphB2; EphB3 double mutants exhibit topographically aberrant projections along the L-M axis (Hindges et al. 2002). The phenotype is equivalent or more severe in mice in which the kinase domain and C terminus of EphB2 is replaced with LacZ, indicating that forward signaling dominates over reverse signaling. These findings imply that EphB-expressing axons are attracted medially by ephrin-B1, in contrast to the repulsive effect of ephrin-B2 at the optic chiasm (Williams et al. 2003). As mentioned in the former section, in Vax2-null mice the expression of $\mathrm{D}-\mathrm{V}$ retinal markers is altered, including a reduced expression of EphB2 and EphB3 in ventral retina, and VT RGCs show a complete shift in their target zones from medial to lateral SC (Barbieri et al. 2002; Mui et al. 2002). The defects in VT RGC mapping in Vax2 mutants are more severe than EphB2; EphB3 double-mutant mice reflecting the transcriptional regulation of Ephs by Vax2 (Hindges et al. 2002). The cell adhesion molecule L1 is transiently expressed by RGC axons during pathfinding and mapping, and L1-null mice have defects in both P-A and L-M mapping in the SC (Demyanenko and Maness 2003). Thus, L1 function is likely required for the accurate performance for EphA and EphB mediated positioning.

Additional work has indicated that in the dLGN, Eph/ ephrin gradients also contribute to RGC topographic target recognition and together with neural activity act to control patterning of eye-specific retinogeniculate layers (Feldheim et al. 2000; McLaughlin et al. 2003a; Garel and Rubenstein 2004; Pfeiffenberger et al. 2005). RGC projections from both eyes initially intermingle, but then segregate postnatally and form eye-specific layers in the dLGN. Ephrin-A2 and ephrin-A5 are expressed in ventral-lateral-anterior-high and dorsal-medial-posteriorlow gradients, whereas ephrin-A3 is expressed in small amounts in the dLGN. In ephrin-A2; ephrin-A5 double mutants and ephrin-A2; ephrin-A3; ephrin-A5 triple mutants, eye-specific inputs segregate but the shape and lo- cation of eye-specific layers are profoundly disrupted (Pfeiffenberger et al. 2005). Mice lacking the $\beta 2$ subunit of nicotinic acetylcholine receptor do not segregate eyespecific inputs and lack correlated RGC spiking and calcium waves (McLaughlin et al. 2003b). Inhibition of correlated neural activity by a nicotinic acetylcholine receptor antagonist in ephrin-A2; ephrin-A3; ephrin-A5 triple mutants leads to overlapping retinal projections that are located in inappropriate regions of the dLGN, suggesting that regions of the dLGN that are normally occupied by the contralateral eye become competent for innervation from either eye (Pfeiffenberger et al. 2005).

\section{Thalamocortical (TC) projections}

In the mammalian brain, reciprocal connections between sensory nuclei of the dLGN and visual cortical area of the neocortex are essential for the relay and processing of visual information (Garel and Rubenstein 2004). Recent studies have shown that activity-dependent mechanisms may not be required for the generation of topography of somatosensory and visual cortical maps (Crair 1999; Katz and Crowley 2002). These results suggest that activity-independent mechanisms must be required for the generation of topographic maps in the cortex. During development, TC axons grow into the subcortical telencephalon $(\mathrm{ST})$, where postnatally they continue on their paths to the cortex. Recent studies have suggested the requirement of some guidance cues in the ST, which may have a key role in controlling the initial topography of thalamic projections to the neocortex. For example, Ebf1, a bHLH transcription factor that is expressed in the dorsal thalamus (DT), ST, and marginal zone of the cerebral cortex, specifies the mapping of TC axons (Fig. 7). Ebf1 mutant embryos project dLGN axons abnormally into the amygdalar region or become trapped in the ST. Ebf1-null TC axons outside the dLGN reach the cerebral cortex but show a global caudal shift in topography (Garel et al. 2002). This shift occurs in the absence of an apparent change in thalamic or neocortical reorganization, and is preceded by a shift in the positions of thalamic axons in the ST. The Dlx1 and Dlx2 homeodomain transcription factors are expressed in the ventral thalamus and ST, but are absent from the DT and
Figure 7. Developmental pathfinding of TC axon projections. Ebf1, Dlx1, and Dlx2 expressed in the thalamus and ST affect the relative positioning of TC axons during embryonic development. In addition, EphAs in the DT and ephrin-As in the ST may control the targeting of the dLGN axons to the visual cortex (VC). After birth, TrkC-expressing dLGN axons target to layer 4 of the visual cortex where neurotrophin-3 (NT-3) is expressed. (dLGN) Dorsal lateral geniculate nucleus; (DT) dorsal thalamus; (VT) ventral thalamus; (ST) subcortical telencephalon.

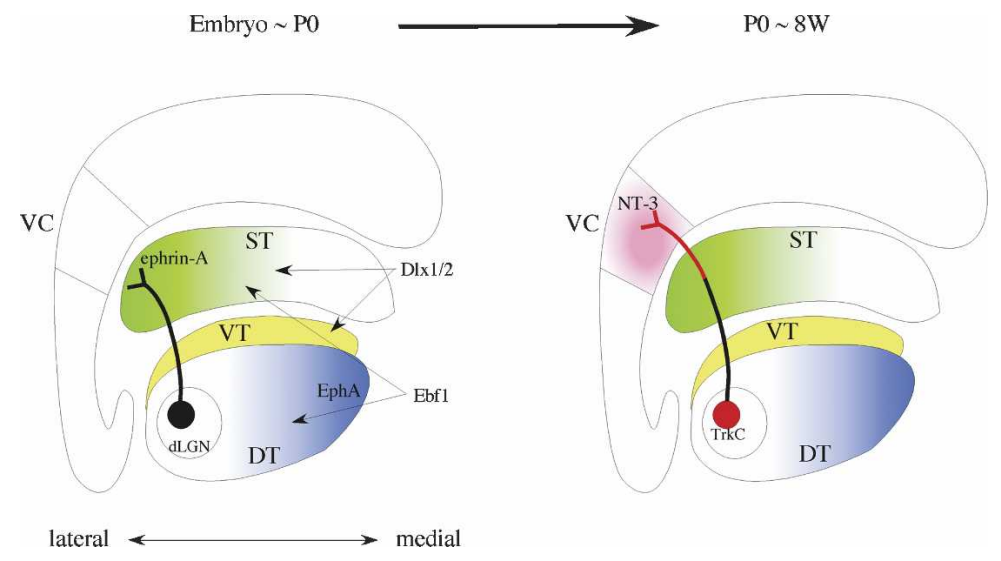


cortical neurons. In Dlx1; Dlx2 double-mutant embryos, some thalamic axons including axons from the dLGN fail to grow and remain in the ST, and the other axons reach the cortex but exhibit a similar shift in topography, as observed in Ebf1 mutants (Garel et al. 2002). On the other hand, EphAs in the thalamus and ephrin-As in the ST are involved in the regulation of TC projections in the somatosensory area in the frontal cortex (Dufour et al. 2003). These findings suggest that various genes affecting the relative positioning of TC axons within the ST may modify the cortical area, including the visual cortex.

Neurotrophins also influence the process of formation of TC connections. Both BDNF and NT-3 are expressed in the cerebral cortex during the critical period when TC axons invade the cortical plate and establish layer-specific synaptic connections with cortical neurons (Lein et al. 2000). Infusion of BDNF or blockade of TrkB signaling inhibits the formation of ocular dominance columns in the cat visual cortex (Cabelli et al. 1997); however, eyespecific segregation of visual inputs to the SC and the dLGN is normal in BDNF knockout mice and conditional mutant in which BDNF expression is absent in the CNS (BDNF ${ }^{\text {flox/flox }}$;nestin-Cre mice) (Lyckman et al. 2005). The absence of BDNF might be compensated by other trophic factors such as NT-4/5. NT-3 is specifically expressed in the layer 4 of the cat visual cortex, both before and during the critical period of TC synapse formation (Lein et al. 2000), and in mice is abundant in specific cortical subregions from P0 until early adulthood (8 wk), whereupon it greatly reduces (Vigers et al. 2000). Conditional mutants in which NT-3 is completely deleted in the cerebral cortex result in reduction of TC projections to the visual cortex, and show a phenotype of impaired visual function, which is one of relative cortical blindness (Ma et al. 2002). These findings implicate neurotrophins in the critical stage of precise TC projections to the visual cortex (Fig. 7). Further studies to reveal the detailed function of neurotrophins during the development of the whole visual pathway may provide important information for the progress of therapeutic methods in RGC protection, regeneration, and rearrangement of TC connections.

\section{Conclusions}

Recent studies have shown that stage- and site-specific intrinsic molecules and extrinsic growth/trophic factors control the early eye formation, retinal differentiation, RGC axon path finding, and topographic mapping. These experimental molecular and genetic findings begin to provide a comprehensive picture of the intricate interplay between transcription factors and signaling at the cell membrane that leads to the complex and precise wiring achieved by the visual system.

\section{Acknowledgments}

We are grateful to Dr. M.A. Dyer for critical review of the manuscript, and Dr. Y. Sakai for his assistance and helpful discus- sions. We apologize if we have inadvertently omitted pertinent references. This work was supported by Grants-in-Aid from the Ministry of Education, Science, Sports, and Culture of Japan to T.H. and C.H., and by NINDS R37NS33199, DOD, and ACS to L.F.P.

\section{References}

Alvarez-Buylla, A. and Lim, D.A. 2004. For the long run: Maintaining germinal niches in the adult brain. Neuron 41: 683686.

Bajenaru, M.L., Zhu, Y., Hedrick, N.M., Donahoe, J., Parada, L.F., and Gutmann, D.H. 2002. Astrocyte-specific inactivation of the neurofibromatosis 1 gene (NF1) is insufficient for astrocytoma formation. Mol. Cell. Biol. 22: 5100-5113.

Barbieri, A.M., Broccoli, V., Bovolenta, P., Alfano, G., Marchitiello, A., Mocchetti, C., Crippa, L., Bulfone, A., Marigo, V., Ballabio, A., et al. 2002. Vax2 inactivation in mouse determines alteration of the eye dorsal-ventral axis, misrouting of the optic fibres and eye coloboma. Development 129: 805813.

Baumer, N., Marquardt, T., Stoykova, A., Ashery-Padan, R., Chowdhury, K., and Gruss, P. 2002. Pax6 is required for establishing naso-temporal and dorsal characteristics of the optic vesicle. Development 129: 4535-4545.

Bertuzzi, S., Hindges, R., Mui, S.H., O'Leary, D.D., and Lemke, G. 1999. The homeodomain protein vaxl is required for axon guidance and major tract formation in the developing forebrain. Genes \& Dev. 13: 3092-3105.

Birgbauer, E., Cowan, C.A., Sretavan, D.W., and Henkemeyer, M. 2000. Kinase independent function of EphB receptors in retinal axon pathfinding to the optic disc from dorsal but not ventral retina. Development 127: 1231-1241.

Birgbauer, E., Oster, S.F., Severin, C.G., and Sretavan, D.W. 2001. Retinal axon growth cones respond to EphB extracellular domains as inhibitory axon guidance cues. Development 128: 3041-3048.

Brittis, P.A., Canning, D.R., and Silver, J. 1992. Chondroitin sulfate as a regulator of neuronal patterning in the retina. Science 255: 733-736.

Brittis, P.A., Lemmon, V., Rutishauser, U., and Silver, J. 1995. Unique changes of ganglion cell growth cone behavior following cell adhesion molecule perturbations: A time-lapse study of the living retina. Mol. Cell. Neurosci. 6: 433-449.

Brown, A., Yates, P.A., Burrola, P., Ortuno, D., Vaidya, A., Jessell, T.M., Pfaff, S.L., O'Leary, D.D., and Lemke, G. 2000. Topographic mapping from the retina to the midbrain is controlled by relative but not absolute levels of EphA receptor signaling. Cell 102: 77-88.

Brown, N.L., Patel, S., Brzezinski, J., and Glaser, T. 2001. Math5 is required for retinal ganglion cell and optic nerve formation. Development 128: 2497-2508.

Brunet, I., Weinl, C., Piper, M., Trembleau, A., Volovitch, M., Harris, W., Prochiantz, A., and Holt, C. 2005. The transcription factor Engrailed-2 guides retinal axons. Nature 438: 94 98.

Burne, J.F. and Raff, M.C. 1997. Retinal ganglion cell axons drive the proliferation of astrocytes in the developing rodent optic nerve. Neuron 18: 223-230.

Cabelli, R.J., Shelton, D.L., Segal, R.A., and Shatz, C.J. 1997. Blockade of endogenous ligands of trkB inhibits formation of ocular dominance columns. Neuron 19: 63-76.

Campbell, K. and Gotz, M. 2002. Radial glia: Multi-purpose cells for vertebrate brain development. Trends Neurosci. 25: 235-238. 
Cellerino, A., Carroll, P., Thoenen, H., and Barde, Y.A. 1997. Reduced size of retinal ganglion cell axons and hypomyelination in mice lacking brain-derived neurotrophic factor. Mol. Cell. Neurosci. 9: 397-408.

Cepko, C.L. 1999. The roles of intrinsic and extrinsic cues and bHLH genes in the determination of retinal cell fates. Curr. Opin. Neurobiol. 9: 37-46.

Chen, S., Wang, Q.L., Nie, Z., Sun, H., Lennon, G., Copeland, N.G., Gilbert, D.J., Jenkins, N.A., and Zack, D.J. 1997. Crx, a novel Otx-like paired-homeodomain protein, binds to and transactivates photoreceptor cell-specific genes. Neuron 19: 1017-1030.

Crair, M.C. 1999. Neuronal activity during development: Permissive or instructive? Curr. Opin. Neurobiol. 9: 88-93.

Cui, Q. and Harvey, A.R. 1995. At least two mechanisms are involved in the death of retinal ganglion cells following target ablation in neonatal rats. J. Neurosci. 15: 8143-8155.

Dakubo, G.D., Wang, Y.P., Mazerolle, C., Campsall, K., McMahon, A.P., and Wallace, V.A. 2003. Retinal ganglion cellderived sonic hedgehog signaling is required for optic disc and stalk neuroepithelial cell development. Development 130: $2967-2980$

Deiner, M.S., Kennedy, T.E., Fazeli, A., Serafini, T., TessierLavigne, M., and Sretavan, D.W. 1997. Netrin 1 and DCC mediate axon guidance locally at the optic disc: Loss of function leads to optic nerve hypoplasia. Neuron 19: 575-589.

Demyanenko, G.P. and Maness, P.F. 2003. The L1 cell adhesion molecule is essential for topographic mapping of retinal axons. J. Neurosci. 23: 530-538.

Drescher, U., Bonhoeffer, F., and Muller, B.K. 1997. Eph family in retinal axon guidance. Curr. Opin. Neurobiol. 7: 75-80.

Dufour, A., Seibt, J., Passante, L., Depaepe, V., Ciossek, T., Frisen, J., Kullander, K., Flanagan, J.G., Polleux, F., and Vanderhaeghen, P. 2003. Area specificity and topography of thalamocortical projections are controlled by ephrin/Eph genes. Neuron 39: 453-465.

Dyer, M.A., Livesey, F.J., Cepko, C.L., and Oliver, G. 2003. Proxl function controls progenitor cell proliferation and horizontal cell genesis in the mammalian retina. Nat. Genet. 34: 53-58.

Feldheim, D.A., Kim, Y.I., Bergemann, A.D., Frisen, J., Barbacid, M., and Flanagan, J.G. 2000. Genetic analysis of ephrin-A2 and ephrin-A5 shows their requirement in multiple aspects of retinocollicular mapping. Neuron 25: 563-574.

Fischer, A.J. 2005. Neural regeneration in the chick retina. Prog. Retin. Eye Res. 24: 161-182.

Frade, J.M. and Barde, Y.A. 1999. Genetic evidence for cell death mediated by nerve growth factor and the neurotrophin receptor p75 in the developing mouse retina and spinal cord. Development 126: 683-690.

Furukawa, T., Morrow, E.M., and Cepko, C.L. 1997. Crx, a novel otx-like homeobox gene, shows photoreceptor-specific expression and regulates photoreceptor differentiation. Cell 91: $531-541$.

Furukawa, T., Mukherjee, S., Bao, Z.Z., Morrow, E.M., and Cepko, C.L. 2000. rax, Hes1, and notch1 promote the formation of Müller glia by postnatal retinal progenitor cells. Neuron 26: 383-394.

Garel, S. and Rubenstein, J.L. 2004. Intermediate targets in formation of topographic projections: Inputs from the thalamocortical system. Trends Neurosci. 27: 533-539.

Garel, S., Yun, K., Grosschedl, R., and Rubenstein, J.L. 2002. The early topography of thalamocortical projections is shifted in Ebf1 and Dlx1/2 mutant mice. Development 129: 5621-5634.

Gonzalez-Hoyuela, M., Barbas, J.A., and Rodriguez-Tebar, A.
2001. The autoregulation of retinal ganglion cell number Development 128: 117-124.

Hallonet, M., Hollemann, T., Pieler, T., and Gruss, P. 1999. Vax1, a novel homeobox-containing gene, directs development of the basal forebrain and visual system. Genes \& Dev. 13: 3106-3114.

Harada, T., Harada, C., Nakayama, N., Okuyama, S., Yoshida, K., Kohsaka, S., Matsuda, H., and Wada, K. 2000. Modification of glial-neuronal cell interactions prevents photoreceptor apoptosis during light-induced retinal degeneration. Neuron 26: $533-541$.

Harada, C., Harada, T., Quah, H.M., Namekata, K., Yoshida, K. Ohno, S., Tanaka, K., and Parada, L.F. 2005. Role of neurotrophin-4/5 in neural cell death during retinal development and ischemic retinal injury in vivo. Invest. Ophthalmol. Vis. Sci. 46: 669-673.

Harada, C., Harada, T., Nakamura, K., Sakai, Y., Tanaka, K., and Parada, L.F. 2006. Effect of $\mathrm{p} 75^{\mathrm{NTR}}$ on the regulation of naturally occuring cell death and retinal ganglion cell number in the mouse eye. Dev. Biol. 290: 57-65.

Hatakeyama, J. and Kageyama, R. 2004. Retinal cell fate determination and bHLH factors. Semin. Cell Dev. Biol. 15: 8389.

Hatakeyama, J., Tomita, K., Inoue, T., and Kageyama, R. 2001. Roles of homeobox and bHLH genes in specification of a retinal cell type. Development 128: 1313-1322.

Hatini, V., Tao, W., and Lai, E. 1994. Expression of winged helix genes, BF-1 and BF-2, define adjacent domains within the developing forebrain and retina. J. Neurobiol. 25: 1293-1309.

Herrera, E., Brown, L., Aruga, J., Rachel, R.A., Dolen, G., Mikoshiba, K., Brown, S., and Mason, C.A. 2003. Zic2 patterns binocular vision by specifying the uncrossed retinal projection. Cell 114: 545-557.

Hindges, R., McLaughlin, T., Genoud, N., Henkemeyer, M., and O'Leary, D.D. 2002. EphB forward signaling controls directional branch extension and arborization required for dorsalventral retinotopic mapping. Neuron 35: 475-487.

Hojo, M., Ohtsuka, T., Hashimoto, N., Gradwohl, G., Guillemot, F., and Kageyama, R. 2000. Glial cell fate specification modulated by the bHLH gene Hes 5 in mouse retina. Development 127: 2515-2522.

Holt, C.E., Bertsch, T.W., Ellis, H.M., and Harris, W.A. 1988. Cellular determination in the Xenopus retina is independent of lineage and birth date. Neuron 1: 15-26.

Hopker, V.H., Shewan, D., Tessier-Lavigne, M., Poo, M., and Holt, C. 1999. Growth-cone attraction to netrin-1 is converted to repulsion by laminin-1. Nature 401: 69-73.

Hu, H. 2001. Cell-surface heparan sulfate is involved in the repulsive guidance activities of Slit2 protein. Nat. Neurosci. 4: 695-701.

Huh, S., Hatini, V., Marcus, R.C., Li, S.C., and Lai, E. 1999. Dorsal-ventral patterning defects in the eye of BF-1-deficient mice associated with a restricted loss of shh expression. Dev. Biol. 211: 53-63.

Ikeda, H., Osakada, F., Watanabe, K., Mizuseki, K., Haraguchi, T., Miyoshi, H., Kamiya, D., Honda, Y., Sasai, N., Yoshimura, N., et al. 2005. Generation of Rx+/Pax6+ neural retinal precursors from embryonic stem cells. Proc. Natl. Acad. Sci. 102: 11331-11336.

Inatani, M., Irie, F., Plump, A.S., Tessier-Lavigne, M., and Yamaguchi, Y. 2003. Mammalian brain morphogenesis and midline axon guidance require heparan sulfate. Science 302: 1044-1046.

Inoue, T., Hojo, M., Bessho, Y., Tano, Y., Lee, J.E., and Kageyama, R. 2002. Math3 and NeuroD regulate amacrine cell fate specification in the retina. Development 129: 831-842. 
Inoue, T., Kagawa, T., Fukushima, M., Shimizu, T., Yoshinaga, Y., Takada, S., Tanihara, H., and Taga, T. 2006. Activation of canonical Wnt pathway promotes proliferation of retinal stem cells derived from adult mouse ciliary margin. Stem Cells 24: 95-104.

Isenmann, S., Kretz, A., and Cellerino, A. 2003. Molecular determinants of retinal ganglion cell development, survival, and regeneration. Prog. Retin. Eye Res. 22: 483-543.

Itasaki, N. and Nakamura, H. 1996. A role for gradient en expression in positional specification on the optic tectum. Neuron 16: 55-62.

Jeffery, G. 2001. Architecture of the optic chiasm and the mechanisms that sculpt its development. Physiol. Rev. 81: 1393-1414.

Katz, L.C. and Crowley, J.C. 2002. Development of cortical circuits: Lessons from ocular dominance columns. Nat. Rev. Neurosci. 3: 34-42.

Kim, J., Wu, H.H., Lander, A.D., Lyons, K.M., Matzuk, M.M., and Calof, A.L. 2005. GDF11 controls the timing of progenitor cell competence in developing retina. Science 308: 19271930.

Koshiba-Takeuchi, K., Takeuchi, J.K., Matsumoto, K., Momose, T., Uno, K., Hoepker, V., Ogura, K., Takahashi, N., Nakamura, H., Yasuda, K., et al. 2000. Tbx5 and the retinotectum projection. Science 287: 134-137.

Lein, E.S., Hohn, A., and Shatz, C.J. 2000. Dynamic regulation of BDNF and NT-3 expression during visual system development. J. Comp. Neurol. 420: 1-18.

Listernick, R. and Gutmann, D.H. 1999. Tumors of the optic pathway. In Neurofibromatosis: Phenotype, natural history, and pathogenesis (eds. J.M. Friedman et al.), pp. 203-230. Johns Hopkins Press, Baltimore, MD.

Liu, I.S., Chen, J.D., Ploder, L., Vidgen, D., van der Kooy, D., Kalnins, V.I., and McInnes, R.R. 1994. Developmental expression of a novel murine homeobox gene (Chx10): Evidence for roles in determination of the neuroretina and inner nuclear layer. Neuron 13: 377-393.

Liu, W., Wang, J.H., and Xiang, M. 2000. Specific expression of the LIM/homeodomain protein Lim-1 in horizontal cells during retinogenesis. Dev. Dyn. 217: 320-325.

Logan, C., Wizenmann, A., Drescher, U., Monschau, B., Bonhoeffer, F., and Lumsden, A. 1996. Rostral optic tectum acquires caudal characteristics following ectopic engrailed expression. Curr. Biol. 6: 1006-1014.

Long, H., Sabatier, C., Ma, L., Plump, A., Yuan, W., Ornitz, D.M., Tamada, A., Murakami, F., Goodman, C.S., and Tessier-Lavigne, M. 2004. Conserved roles for Slit and Robo proteins in midline commissural axon guidance. Neuron 42: 213-223.

Lyckman, A.W., Fan, G., Rios, M., Jaenisch, R., and Sur, M. 2005. Normal eye-specific patterning of retinal inputs to murine subcortical visual nuclei in the absence of brain-derived neurotrophic factor. Vis. Neurosci. 22: 27-36.

Ma, Y.T., Hsieh, T., Forbes, M.E., Johnson, J.E., and Frost, D.O. 1998. BDNF injected into the superior colliculus reduces developmental retinal ganglion cell death. J. Neurosci. 18: 2097-2107.

Ma, L., Harada, T., Harada, C., Romero, M., Hebert, J.M., McConnell, S.K., and Parada, L.F. 2002. Neurotrophin-3 is required for appropriate establishment of thalamocortical connections. Neuron 36: 623-634.

Macdonald, R., Barth, K.A., Xu, Q., Holder, N., Mikkola, I., and Wilson, S.W. 1995. Midline signalling is required for Pax gene regulation and patterning of the eyes. Development 121: 3267-3278.

Maher, E.A., Furnari, F.B., Bachoo, R.M., Rowitch, D.H., Louis,
D.N., Cavenee, W.K., and DePinho, R.A. 2001. Malignant glioma: Genetics and biology of a grave matter. Genes \& Dev. 15: 1311-1333.

Mann, F., Harris, W.A., and Holt, C.E. 2004. New views on retinal axon development: A navigation guide. Int. J. Dev. Biol. 48: 957-964.

Marquardt, T. and Gruss, P. 2002. Generating neuronal diversity in the retina: One for nearly all. Trends Neurosci. 25: 32-38.

Marquardt, T., Ashery-Padan, R., Andrejewski, N., Scardigli, R., Guillemot, F., and Gruss, P. 2001. Pax6 is required for the multipotent state of retinal progenitor cells. Cell 105: 43-55.

McLaughlin, T. and O'Leary, D.D. 2005. Molecular gradients and development of retinotopic maps. Annu. Rev. Neurosci. 28: $327-355$

McLaughlin, T., Hindges, R., and O'Leary, D.D. 2003a. Regulation of axial patterning of the retina and its topographic mapping in the brain. Curr. Opin. Neurobiol. 13: 57-69.

McLaughlin, T., Torborg, C.L., Feller, M.B., and O'Leary, D.D. 2003b. Retinotopic map refinement requires spontaneous retinal waves during a brief critical period of development. Neuron 40: 1147-1160.

Morrow, E.M., Furukawa, T., Lee, J.E., and Cepko, C.L. 1999. NeuroD regulates multiple functions in the developing neural retina in rodent. Development 126: 23-36.

Mui, S.H., Hindges, R., O'Leary, D.D., Lemke, G., and Bertuzzi, S. 2002. The homeodomain protein Vax2 patterns the dorsoventral and nasotemporal axes of the eye. Development 129: 797-804.

Nishida, A., Furukawa, A., Koike, C., Tano, Y., Aizawa, S., Matsuo, I., and Furukawa, T. 2003. Otx2 homeobox gene controls retinal photoreceptor cell fate and pineal gland development. Nat. Neurosci. 6: 1255-1263.

Nykjaer, A., Lee, R., Teng, K.K., Jansen, P., Madsen, P., Nielsen, M.S., Jacobsen, C., Kliemannel, M., Schwarz, E., Willnow, T.E., et al. 2004. Sortilin is essential for proNGF-induced neuronal cell death. Nature 427: 843-848.

Oliver, G., Mailhos, A., Wehr, R., Copeland, N.G., Jenkins, N.A., and Gruss, P. 1995. Six3, a murine homologue of the sine oculis gene, demarcates the most anterior border of the developing neural plate and is expressed during eye development. Development 121: 4045-4055.

Ono, K., Yasui, Y., Rutishauser, U., and Miller, R.H. 1997. Focal ventricular origin and migration of oligodendrocyte precursors into the chick optic nerve. Neuron 19: 283-292.

Ooto, S., Akagi, T., Kageyama, R., Akita, J., Mandai, M., Honda, Y., and Takahashi, M. 2004. Potential for neural regeneration after neurotoxic injury in the adult mammalian retina. Proc. Natl. Acad. Sci. 101: 13654-13659.

Oster, S.F. and Sretavan, D.W. 2003. Connecting the eye to the brain: The molecular basis of ganglion cell axon guidance. Br. J. Ophthalmol. 87: 639-645.

Oster, S.F., Bodeker, M.O., He, F., and Sretavan, D.W. 2003. Invariant Sema5A inhibition serves an ensheathing function during optic nerve development. Development 130: 775-784.

Perry, V.H., Henderson, Z., and Linden, R. 1983. Postnatal changes in retinal ganglion cell and optic axon populations in the pigmented rat. J. Comp. Neurol. 219: 356-368.

Peters, M.A. 2002. Patterning the neural retina. Curr. Opin. Neurobiol. 12: 43-48.

Pfeiffenberger, C., Cutforth, T., Woods, G., Yamada, J., Renteria, R.C., Copenhagen, D.R., Flanagan, J.G., and Feldheim, D.A. 2005. Ephrin-As and neural activity are required for eye-specific patterning during retinogeniculate mapping. Nat. Neurosci. 8: 1022-1027. 
Plump, A.S., Erskine, L., Sabatier, C., Brose, K., Epstein, C.J., Goodman, C.S., Mason, C.A., and Tessier-Lavigne, M. 2002. Slit 1 and Slit 2 cooperate to prevent premature midline crossing of retinal axons in the mouse visual system. Neuron 33: 219-232.

Rasband, K., Hardy, M., and Chien, C.B. 2003. Generating X: Formation of the optic chiasm. Neuron 39: 885-888.

Rashid, T., Upton, A.L., Blentic, A., Ciossek, T., Knoll, B., Thompson, I.D., and Drescher, U. 2005. Opposing gradients of ephrin-As and EphA7 in the superior colliculus are essential for topographic mapping in the mammalian visual system. Neuron 47: 57-69.

Sakuta, H., Suzuki, R., Takahashi, H., Kato, A., Shintani, T., Iemura, S., Yamamoto, T.S., Ueno, N., and Noda, M. 2001. Ventroptin: A BMP-4 antagonist expressed in a double-gradient pattern in the retina. Science 293: 111-115.

Satow, T., Bae, S.K., Inoue, T., Inoue, C., Miyoshi, G., Tomita, K., Bessho, Y., Hashimoto, N., and Kageyama, R. 2001. The basic helix-loop-helix gene hesr2 promotes gliogenesis in mouse retina. J. Neurosci. 21: 1265-1273.

Schulte, D. and Cepko, C.L. 2000. Two homeobox genes define the domain of EphA3 expression in the developing chick retina. Development 127: 5033-5045.

Schulte, D., Furukawa, T., Peters, M.A., Kozak, C.A., and Cepko, C.L. 1999. Misexpression of the Emx-related homeobox genes cVax and $\operatorname{mVax} 2$ ventralizes the retina and perturbs the retinotectal map. Neuron 24: 541-553.

Spassky, N., de Castro, F., Le Bras, B., Heydon, K., QueraudLeSaux, F., Bloch-Gallego, E., Chedotal, A., Zalc, B., and Thomas, J.L. 2002. Directional guidance of oligodendroglial migration by class 3 semaphorins and netrin-1. J. Neurosci. 22: 5992-6004.

Sugimoto, Y., Taniguchi, M., Yagi, T., Akagi, Y., Nojyo, Y., and Tamamaki, N. 2001. Guidance of glial precursor cell migration by secreted cues in the developing optic nerve. Development 128: 3321-3330.

Teng, H.K., Teng, K.K., Lee, R., Wright, S., Tevar, S., Almeida, R.D., Kermani, P., Torkin, R., Chen, Z.Y., Lee, F.S., et al. 2005. ProBDNF induces neuronal apoptosis via activation of a receptor complex of p75NTR and sortilin. J. Neurosci. 25: $5455-5463$.

Tomita, K., Ishibashi, M., Nakahara, K., Ang, S.L., Nakanishi, S., Guillemot, F., and Kageyama, R. 1996a. Mammalian hairy and Enhancer of split homolog 1 regulates differentiation of retinal neurons and is essential for eye morphogenesis. Neuron 16: 723-734.

Tomita, K., Nakanishi, S., Guillemot, F., and Kageyama, R. 1996b. Mash1 promotes neuronal differentiation in the retina. Genes Cells 1: 765-774.

Tomita, K., Moriyoshi, K., Nakanishi, S., Guillemot, F., and Kageyama, R. 2000. Mammalian achaete-scute and atonal homologs regulate neuronal versus glial fate determination in the central nervous system. EMBO I. 19: 5460-5472.

Tropepe, V., Coles, B.L., Chiasson, B.J., Horsford, D.J., Elia, A.J., McInnes, R.R., and van der Kooy, D. 2000. Retinal stem cells in the adult mammalian eye. Science 287: 2032-2036.

Turner, D.L. and Cepko, C.L. 1987. A common progenitor for neurons and glia persists in rat retina late in development. Nature 328: 131-136.

Turner, D.L., Snyder, E.Y., and Cepko, C.L. 1990. Lineage-independent determination of cell type in the embryonic mouse retina. Neuron 4: 833-845.

Tsai, H.H. and Miller, R.H. 2002. Glial cell migration directed by axon guidance cues. Trends Neurosci. 25: 173-175.

Vigers, A.J., Baquet, Z.C., and Jones, K.R. 2000. Expression of neurotrophin-3 in the mouse forebrain: Insights from a tar- geted LacZ reporter. J. Comp. Neurol. 416: 398-415.

von Bartheld, C.S. 1998. Neurotrophins in the developing and regenerating visual system. Histol. Histopathol. 13: 437-459.

Wang, S.W., Kim, B.S., Ding, K., Wang, H., Sun, D., Johnson, R.L., Klein, W.H., and Gan, L. 2001. Requirement for math5 in the development of retinal ganglion cells. Genes \& Dev. 15: 24-29.

Watanabe, T. and Raff, M.C. 1988. Retinal astrocytes are immigrants from the optic nerve. Nature 332: 834-837.

Wetts, R. and Fraser, S.E. 1988. Multipotent precursors can give rise to all major cell types of the frog retina. Science 239: $1142-1145$.

Wilkinson, D.G. 2000. Topographic mapping: Organising by repulsion and competition? Curr. Biol. 10: R447-R451.

Williams, S.E., Mann, F., Erskine, L., Sakurai, T., Wei, S., Rossi, D.J., Gale, N.W., Holt, C.E., Mason, C.A., and Henkemeyer, M. 2003. Ephrin-B2 and EphB1 mediate retinal axon divergence at the optic chiasm. Neuron 39: 919-935.

Williams, S.E., Mason, C.A., and Herrera, E. 2004. The optic chiasm as a midline choice point. Curr. Opin. Neurobiol. 14: $51-60$.

Woo, N.H., Teng, H.K., Siao, C.J., Chiaruttini, C., Pang, P.T., Milner, T.A., Hempstead, B.L., and Lu, B. 2005. Activation of p75NTR by proBDNF facilitates hippocampal long-term depression. Nat. Neurosci. 8: 1069-1077.

Yang, X.J. 2004. Roles of cell-extrinsic growth factors in vertebrate eye pattern formation and retinogenesis. Semin. Cell Dev. Biol. 15: 91-103.

Yuasa, J., Hirano, S., Yamagata, M., and Noda, M. 1996. Visual projection map specified by topographic expression of transcription factors in the retina. Nature 382: 632-635.

Zhang, X.M. and Yang, X.J. 2001. Temporal and spatial effects of Sonic hedgehog signaling in chick eye morphogenesis. Dev. Biol. 233: 271-290.

Zhu, Y. and Parada, L.F. 2002. The molecular and genetic basis of neurological tumours. Nat. Rev. Cancer 2: 616-626.

Zhu, Y., Harada, T., Lush, M.E., Guignard, F., Liu, L., Harada, C., Burns, D.K., Bajenaru, M.L., Gutmann, D.H., Messing, A., et al. 2005. Inactivation of NF1 in CNS causes increased proliferation in glial progenitor cells and is sufficient to induce optic gliomas. Development 132: 5577-5588. 


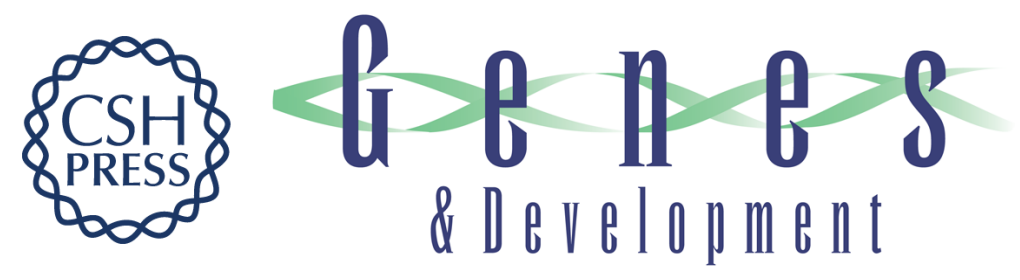

\section{Molecular regulation of visual system development: more than meets the eye}

Takayuki Harada, Chikako Harada and Luis F. Parada

Genes Dev. 2007, 21:

Access the most recent version at doi:10.1101/gad.1504307

$\begin{array}{ll}\text { References } & \text { This article cites } 117 \text { articles, } 41 \text { of which can be accessed free at: } \\ \text { http://genesdev.cshlp.org/content/21/4/367.full.html\#ref-list-1 }\end{array}$

License

Email Alerting Receive free email alerts when new articles cite this article - sign up in the box at the top Service right corner of the article or click here.

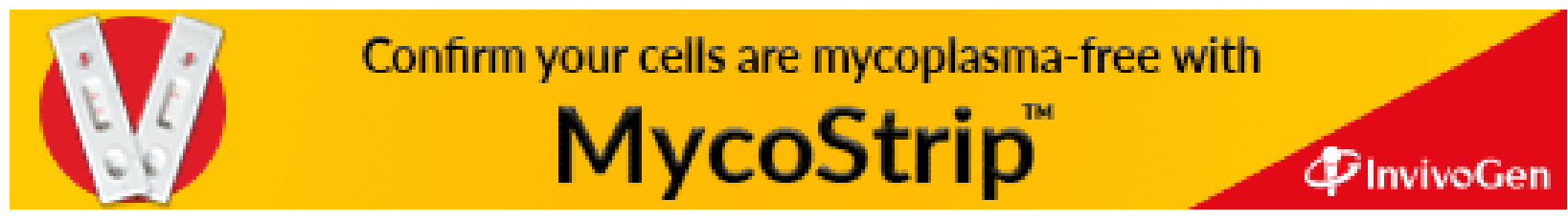

